\title{
The Fragility of Togetherness: Reflections On the City, Home and Family
}

Sertaç Timur Demir ${ }^{1}$

The Fragility of Togetherness: Reflections On the City, Home and Family

Abstract
This article deals with the home and family as socio-
economic projections of urban fate through the film Kö-
prüdekiler (Men on the Bridge, 2009). Accordingly, a
desire for having a better life suppresses spatial expec-
tations and triggers family conflicts. At this point, just
as family bonds do not correspond to unconditional
commitments, home is no longer a mental or spiritual
shelter for couples. Belongings are ambivalent; intima-
cies are uncanny, and ties are weak. In this article, the
condition of social fragility is debated through two
characters, Umut and Cemile, in the film. They are mar-
ried but unhappy. Köprüdekiler is a film that zooms in
the lives of those who are pushed away from the centre
to the margins of society in Istanbul. In this paper, it is
concentrated on the city as being both a hopeful and dis-
appointing dilemma; on the home as a place of vulner-
ability; and on the family as a modern symbol of fragil-
ity. The analysed awarded-film deepens and elaborates
the socio-urban reality by reflecting it simply as it is.

Keywords: the City, home, family, togetherness, conflict, Men on the Bridge
Birlikteliğin Kırılganlığı: Kent, Ev ve Aile Üzerindeki Yansimalar

$\ddot{O} z$

Bu makale Köprüdekiler (Men on the Bridge, 2009) filmi üzerinden evi ve aileyi kentsel yazgının sosyo-ekonomik izdüşümleri olarak ele almaktadır. Buna göre, daha iyi bir yaşam isteği, mekânsal beklentileri baskılamakta ve ailevi bölünmeyi tetiklemektedir. Gelinen noktada, aile bağları koşulsuz taahhütlere karşılık gelmediği gibi, ev de çiftler için artık mental veya manevi sığınak değildir. Aidiyetler belirsiz, yakınlıklar tekinsiz, bağlar ise zayıftır. Bu makalede bu toplumsal kırılganlık durumu, filmin iki karakteri Umut ve Cemile'nin hikâyesi üzerinden tartışılmaktadır. Umut ve Cemile evlidir, fakat mutsuzlardır. Köprüdekiler filmi İstanbul'da toplumun merkezinden kenarlarına itilen insanların yaşamına yakınlaşmaktadır. Bu çalışmada kente hem umutlu hem de hayal k1rıcı ikilem; eve incinebilirlik yeri; aileye ise kırılganlığın modern sembolü olarak yoğunlaşılmaktadır. Analize konu olan bu ödüllü film bu sosyo-kentsel gerçekliği olduğu gibi yansıtarak derinleştirmekte ve detaylandırmaktadır.

Anahtar Sözcükler: kent, ev, aile, birliktelik, çatışma, Köprüdekiler

\section{Introduction}

Istanbul changes continuously and rapidly. Cinema, as a mean of capturing and reproducing moving images, is a kind of living memory of the city. Sounds, fabrics, tastes, traditions, histories and myths all embody the world of films; therefore, analyzing films can be equivalent to archiving the city. Köprüdekiler, directed by Aslı Özge in 2009, is a story of a desperate couple (Umut and Cemile) who struggles to live in Istanbul. ${ }^{2}$ They represent different intensive but shadowy dimensions of Istanbul. They are also familiar and honest informers about the tragedies, conflicts, revenge, struggle, hopes and disappointments of the city and home. They are bodily close, emotionally distant to each other. This does not only refer to a measurable, physical and geographical but essentially to an mental and emotional distance. The aim of this research is to discuss the effects of the constructive and destructive relationship between space and social structure on the family.

Linked to this, the framework of this article is fictionalised around two characters, each of whom hopes to achieve their dreams but who, nonetheless, somehow fails at every turn. Each of

\footnotetext{
${ }^{1}$ Assoc. Prof. Dr. Sertaç Timur Demir is a Member of Faculty of Coomunication at Gümüşhane University, GümüşhaneTURKEY, stdemir@gumushane.edu.tr, ORCID: 0000-0002-9420-9416.

${ }^{2}$ Indeed, apart from Umut and Cemile, there are two more independent characters and stories in the film: Murat and Fikret. However, in this article, only the story of the couple (Umut and Cemile) is examined.
} 
them has to find their own method of surviving and having a better life. Umut, a dolmus (shared taxi) driver, struggles to find a more comfortable flat to make his wife happy. As for his wife, Cemile, she wants a bigger and better house. These characters in the film interestingly do not play-act - they reflect who they are in real life, so much so that none of them is professional actors. In this respect, one of the most successful sides of this film is its casting and actor directing. The characters and their stories, not to mention the simple, documentary-like way in which the film is filmed, create a warm impression for its viewers; thus, they find themselves in a paused sequence in spite of the passage of time and the liquidity of space.

According to Fatih Akın (2012), a well-known film director, Köprüdekiler is a diamond of current Turkish cinema; a powerful, multi-layered portrait of the complex entity which is Turkish society. The film's language and fiction are so natural and sincere that it may be assumed that it does not have any scenario or written text. The characters, just like in everyday life, sometimes stumble and sometimes forget what they need to say. It is felt by the viewers that as if the characters' acts are recorded by a hidden camera. The director does not use any artificial sound, music, decor or artistic dialogue which might destroy this spontaneity and naturalness. This film uses streets rather than studios and daylight rather than artificial light. It sets more premiums on naturalness and artlessness than on strict rules, static scenarios and far-fetched dialogues. Also, it does not give credit to exaggerated shots, ornamental effects, tricky stories and theatrical acting.

\section{Method of Analysis}

Köprüdekiler transparently tries to gain insight into the lives of the characters and their stabile stories. This is quite worthwhile in that these secondary individuals, although feeling as if they need to hide, compose a major part of the urban population. In other words, they are the most visible - but paradoxically also the least seen — dwellers. The film, nonetheless, aims to highlight their problematic existence. The characters in the film are both needed and disgusted acnes of the city; that is why I place an emphasis on social theory in order to gain insight into their deep lives in the collective being and social organism that is the city (Lefebvre, 1996, p. 95). Theory, just like a key which can open multi-layered, labyrinthic and complicated doors of cities, carries the potential to make them more obvious and watchable. As a consequence of this complexity, the city itself becomes both a golden opportunity and a slippery slope for social scientists (Demir, 2014 , p. 25) who attempt to rewrite what filmmakers display and who attempt to "stray outside the boundaries of the fictive world" (Dowd, 1999, p. 329; cited in Diken and Laustsen, 2007, p. 4).

As a pre-motivation, I focus essentially on what the film highlights concerning the argument instead of stating everything the film tells us; also, I emphasize social and urban experiences and apply theoretical discussions to the film: this can be defined as theorizing the film or filming theory. That is why, The theoretical framework of this paper is based on the works especially of Zygmunt Bauman and Richard Sennett. I support the theoretical background given with the grammar of the film's language.

In this sense, I pay attention to the film's narration, framing, editing, shots, camera angles, sound, acting and dialogues, as well as the characters and the film's story. They, together, help to elaborate both the theory and the film. The theoretical approach is generally seen as the carotid artery in social sciences as well as art and humanities because the theory itself determines the methodology and affects the research's findings (Demir, 2014, p. 29). This is the approach and method that I have tried to follow and apply throughout the paper. 


\section{Umut and Cemile: A Desperate Couple Behind the Insuperable Walls}

During the first forty-five seconds of the film, the camera pans over the Bosphorus Bridge and shows it from beginning to end. The camera moves and waves as if it were mounted on a rowboat. After this forty-five second panoramic presentation, the Bosphorus Bridge is seen in a chaotic atmosphere. The time is evening. People come from their jobs and are struggling to arrive at their homes. This may take hours. The camera, from inside a car, captures the slow and dense crowd of cars creeping along the bridge. Their bright headlights destroy the darkness of the evening. In the following shot, Umut is seen driving a shared taxi.

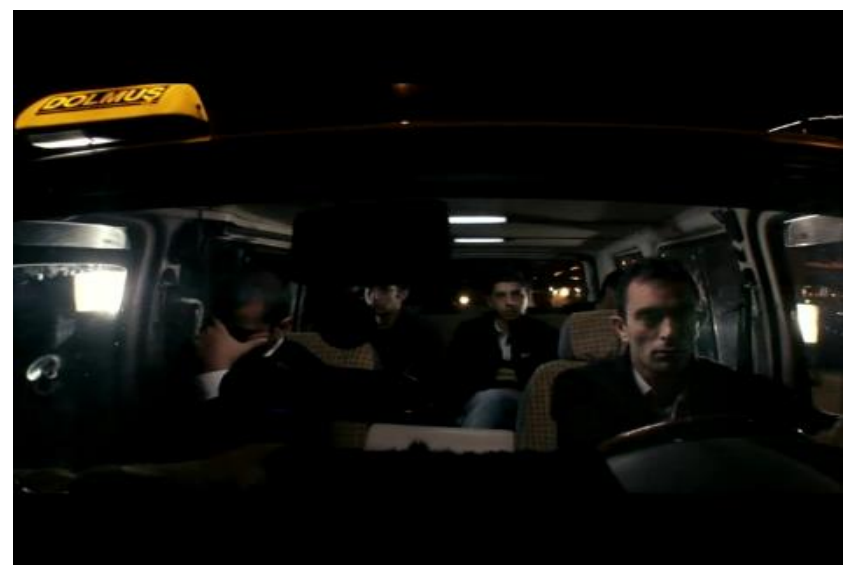

\section{Figure 1.}

Umut drives the shared taxi for hours and sometimes without sleeping. The Bridge is his second home.

Even if the taxi's owner was someone else, he earns his keep by driving it day and night. The bridge is the main transition point along his route. At home, a woman who checks and counts out the money in his pocket, waits for him. This is his wife, Cemile. She is not happy, especially with the house in which they currently reside. According to her, the house is like a small coop and even a suffocating prison. She desires a more comfortable and more luxurious residence in a more secure environment. Hence, she pushes Umut to achieve her desires.

Living in Istanbul - a city in which loneliness can be unbearable - can be insurmountable trouble for couples. The family institution that is theoretically built upon the promise of the sharing of both responsibilities and burdens can also carry new problems with it. Umut and Cemile's is this kind of marriage. Umut drives a shared taxi. He frequently works round the clock and without social security cover. Since the owner of the taxi is someone else, he cannot earn enough money, or at least, his income does not satisfy Cemile. Umut's earnings are, however, far from being able to realize her desire. In this sense, although "Umut" literally means "hope" in Turkish, he represents hopelessness for Cemile. 


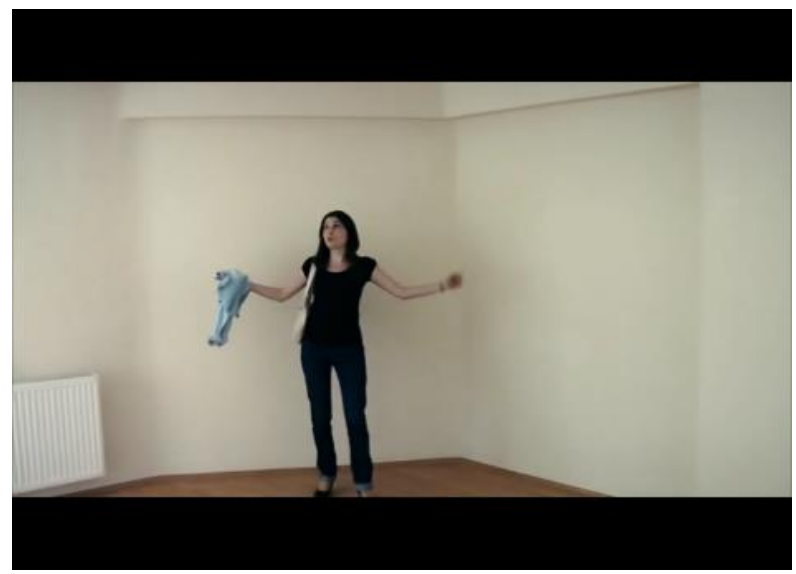

\section{Figure 2.}

Cemile likes a house and imagines herself as the occupant of this good-sized property. The only problem is Umut's shoestring budget. Ultimately, the house also remains another unrealised dream for Cemile.

Cemile believes that she will end up dying in her current house, and insistently forces her husband to get a better one. Somehow, Umut is responsible both for fulfilling their essential requirements and for enhancing the quality of their life. The situation affirms Sennett's observations: "traditionally it has fallen to men to provide shelter, a part of the male portfolio of competence" (Sennett, 2003, p. 112). Therefore, the reason for their living in an insecure and unsatisfactory shelter is, according to Cemile, Umut's incapacity and laziness because she thinks that urban life requires awareness in order to adapt its faster and more complicated rhythm (Simmel, 1971, p. 325). In her sight, Istanbul is the city of endless opportunities and Umut does not struggle enough to reform their lives.

On the other hand, metaphorically, living in the city resembles the act of driving a taxi on a labyrinthic road. Accordingly, there are non-obvious and numerous traffic rules and, in the event that the driver is not sufficiently careful and aware of these rules, he may lose everything in an instant. In other words, in Istanbul, risks and fears accompany opportunities and expectations. On the basis of the seductive curse, possession and wealth in the city are like a "lottery" that everybody hopes to win. However, the winner is always someone else. Grand prizes are tangent to Umut. He experiences spatiality and temporality within a vicious circle by depending on an absolute and tiresome routine. His social fate offers a repetitive cyclicality rather than upward linearity; that is perhaps why he always feels desperate, tired and blasé.

As for Cemile, on the other hand, she lives in a realm in which serenity depends on materiality and happiness depends on a larger house. Even at the cost of losing Umut and ending their marriage, she overstrains Umut's capacity for the purpose of attaining a more comfortable and secure house. She dreams of a luxury lifestyle in an isolated environment because, in her view, the house in which they currently live gives her the feeling of being in a jail which rots her mental vigor and dynamism; whereas, living in a luxurious, isolated world may stimulate a feeling "like intoxicating freedom" (Bauman, 1998a, p. 23). In her sight, freedom can only be attained by taking refuge in condominium-type gated communities which, although spatially inside the city, are nevertheless mentally outside it (Bauman, 2003a, p. 107). In other words, preferring controlled places which are purified from inadequate people is somehow perceived as the quickest way to obtaining freedom (Bauman, 1997, p. 31). In fact, Cemile does not mainly aim to change the house itself; instead, she wants to enhance her socio-economic status. She, however, knows that Umut cannot help her achieve this aim and therefore looks for a more regular and more profitable job than that of babysitting. She wants an office job but knows nothing about computers. Cemile returns empty-handed from all of the job applications which she has filled. Neither 
Umut nor Cemile can make their own dreams come true. Hence, with every passing day, they become more aggressive, nervous and desperate.

The only space in which they feel happy is the Bosphorus. In this representation, the Bosphorus Strait's main characteristic is its sense of freedom, happiness and equality-so much so that the more one moves away from the Bosphorus, the more the traces of spatial segregation and polarization deepen. Accordingly, whenever they go there to watch the sea, they forget who they are- as well as what they do not have. Umut and Cemile, the unhappy couple, kiss passionately when they sit at a seaside park; thus, they suspend their marital conflicts by being inspired by the Bosphorus Strait, as well as by the firework events taking place overhead.

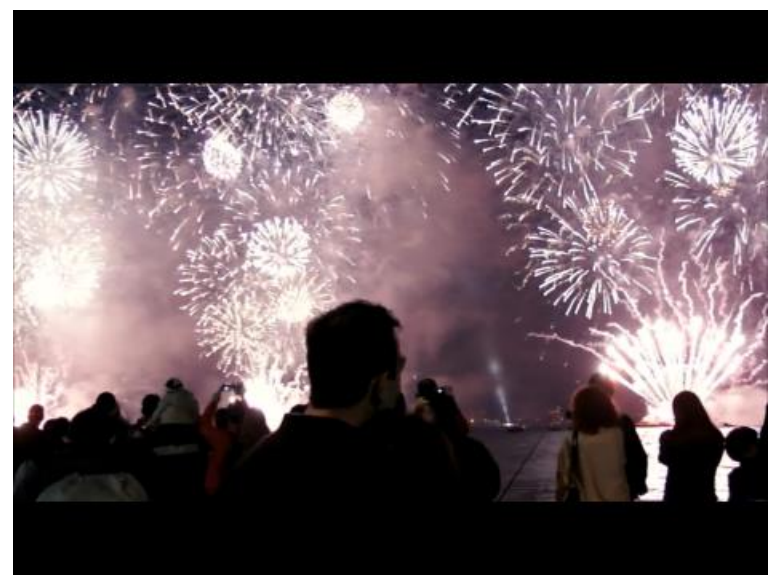

\section{Figure 3.}

Umut and Cemile feel a temporary love, passion and happiness on the Bosphorus Strait under the fireworks. Their joy and serenity, however, is just as temporary as the firework show.

This is the only moment in the film where it seems as if they are happy. However, the most significant feature of the polished and (so) deceptive sense what the Bosphorus creates is its temporality. Just as the Bosphorus does not equalize in an absolute and permanent sense, it underlines the appearance of inequality. For instance, in contrast to the elite minority who resides in houses that view the tempting landscape of the Bosphorus, a great majority of the city population visits and senses temporarily this space in a touristic content. Umut and Cemile are only some of this majority. They do not experience the space itself but its image; in other words, the serenity which they experience is always limited by time and space; similarly, happiness and joy are fragile and may turn into qualm and anxiety at any given moment. For this reason, Umut and Cemile sit in a cafe at the seaside after a passionate kiss and then they start to talk about the same annoying issues:

Cemile: It is back to the same thing: Everything depends on money. And we don't have any. Or else you should get a new job. One that pays a monthly wage. If I moved somewhere better... I mean 'we'. As if I live alone!

Umut: (He deeply thinks and heaves a sigh).

Cemile: After watching all those amazing fireworks...

Umut: We were having a nice time for once! But you ruined it in five minutes.

\section{The Fragility of the City, Home and Family}

The paradoxical love of Umut and Cemile resembles city-living itself: it both attracts and repels (Bauman, 2003b, p. 32). It is not easy to maintain a relationship that is under the influence of bipolar emotions and experiences (such as hopes and poverty; plans and impossibility; desires and reality; etc.); but nor is it possible to end such a relationship either. Moreover, the antinomy 
between these opposite feelings and experiences is instigated by the city itself. For instance, whenever Cemile goes to the city center, she notices the worldly goods which she does not have.

The visible side of city life - a life enlivened with seductive vitrines and avid consumersis ecstatic, sparkling and tempting. Cemile sees other women who feverishly shop. She then unavoidably compares herself with them. She is one who can only see from a distance at what others buy and who constructs herself and her relationships with others mainly within the framework of her own gaze. In other words, she realizes and grasps her existence and the other parameters which separate herself from the society, history, space, norms and values which apply to her by means of unconscious, spontaneous ocular experiences. That is why, the more Cemile goes to the center and observes other lives, the more the cliff-like distance between her and Umut, between her and the worth of the institution of family, and between her and her expectations, increases. This may show that the lifestyle that is accepted under normal circumstances can be unbearable at the moment when they encounter others' sterilised lives ${ }^{3}$. Linked to this, the primary thing that forces her to change and consume is not the stereotypic categorization to which she is subjected but rather is the imprisonment of her own gaze.

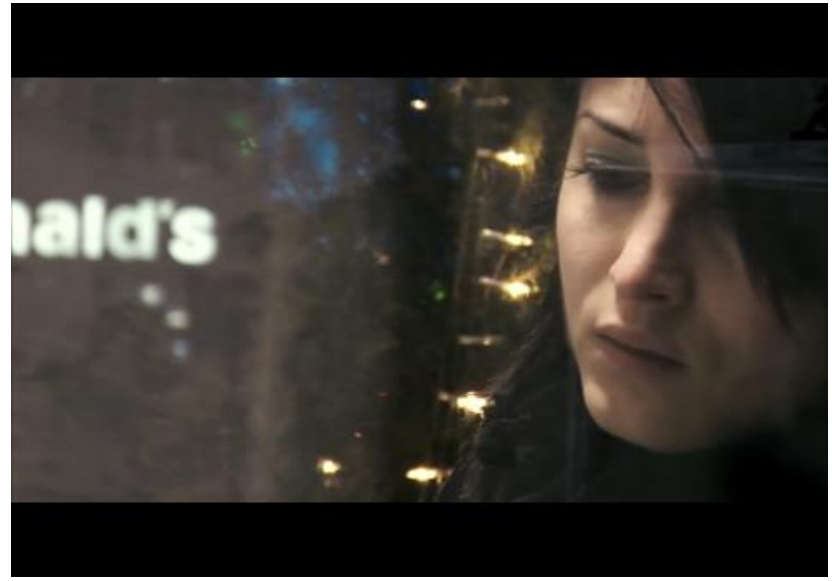

\section{Figure 4}

Cemile is in front of a vitrine. She can only look at trendy and expensive shoes, bags and other products from $a$ distance.

Cemile, as a result of the desires which her gaze arouses, can no longer see her house as a durable shelter. It is now an open target in Istanbul, which itself is the house of uncertainties and fragilities. Since Cemile is not contented with what she has, she even faces the possibility of divorce due to her husband's financial problems. Ironically, there is a calculable amount of happiness in their lives: It is as large as the size of their house. This may imply that Istanbul, which once had been portrayed as the city of love and poetry by Yesilçam movies and travelers, has turned into a city full of couples who prioritize their financial comfort over their emotional attachments - so much so that living in a rented house in itself can be a reason for conflict and divorce. "The city is the impossibility of home; although there was no home prior to the city, a sense of homelessness is engendered by the city" (Lapsley, 1997, p. 194). Besides, homelessness

\footnotetext{
${ }^{3}$ Indeed, it is not possible to claim that there are "sterilised lives" that are entirely purified from all socio-urban problems. I think, the sterilization discourse is based on an artificial and designed perception that is fictionalised essentially around capital values and that is mainly internalised by outsiders like Umut and Cemile. In the meantime, for a comprehensive reading on the issue of "sterile lives", see the book Steril Yaşamlar (Sterile Lives, 2010) written by Köksal Alver. In this book, segregation in urban space, differentiation of spaces, neighborhood, district, house and more specifically the concept of secure site are examined.
} 
is undoubtedly a problem, but the misconfiguration of the home is still a worse problem in the city.

Even though living on the streets as a homeless one might equate to being alone, living in the home in which family members hate and interrogate each other is a more unendurable problem. Namely, the streets may refer to freedom in some way, but the home is, rather paradoxically, the center of conflict and frustration. Perhaps, for this reason, Umut and Cemile look for happiness and serenity on the Bosphorus instead of inside their own home. Home is now a fragile, fugacious and ephemeral social metabolism rather than a supreme and durable castle in this world of ambivalence. Neither the home nor the institution of family which the home represents is a "defensible space" (Bauman, 1998b, p. 135).

It brings to mind anything except a safe haven of duration where one can cast the anchor of one's own vulnerable and admittedly transient existence. As easy to end as it is to start and as easy to dismantle as it is to put together, the family can no more be counted on lasting longer than those who bring it into the world. (Bauman, 1999, p. 41)

The home, in contrast with John Ruskin, who saw and idealised it as a place of peace and as a shelter that saves family members from terror, doubt and division (1891, pp. 136-137; cited in Sennett, 1992, p. 20), is the locus of confrontation and showdown rather than as a catharsis and place for sharing. Moreover, it is the capital of conflict in which, in spite of its physical proximity, consists of a mental and emotional distance which becomes common and dominant. In Umut and Cemile's home, there are huge walls that are bound by unrealised expectations and unsatisfied desires. Besides, the couple is merely a single drop of water in the bucket: the city is full of similar characters who hit these walls almost every single day.

\section{In Search of Togetherness}

At the end of the film, it is still unknown whether they divorce or try once more to reconstruct their relationship. Probably, Umut will continue to drive his taxi because of his not being able to do anything else. The stress and tension that he faces at home will affect his business life as well as his state of mind. Within this frame, his position is open to every kind of negative possibility. In addition to this, since he cannot meet Cemile's expectations and a metropolitan life's habitual requirements, he may even stop his taxi one day and jump from the Bosphorus Bridge. ${ }^{4}$ In any case, his fate is loneliness; the only thing that he needs is a warm togetherness.

\footnotetext{
${ }^{4}$ The Bosphorus Bridge is also a place where many individuals attempt to commit suicide every year.
} 


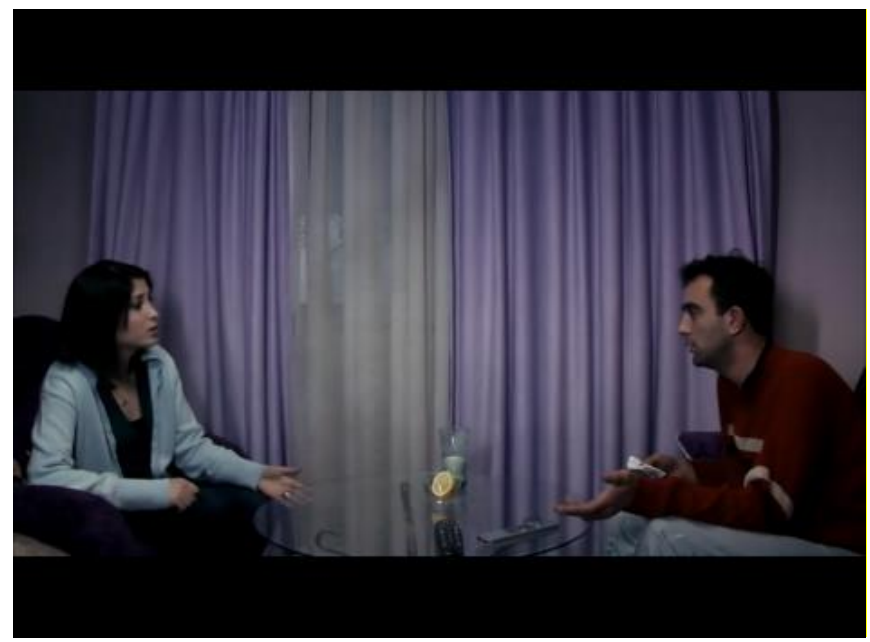

\section{Figure 5}

Umut and Cemile argue about how they will overcome their financial difficulties.

Sennett conceptualizes the concept togetherness with that of community and a sense of character (1998, p. 135). According to him, those who are doomed to fail under the influence of modern capitalism are those in need of a larger sense of community and a fuller sense of character (ibid.). "The 'we' feeling, which expresses the desire to be similar" (Sennett, 1996, pp. 39-42; cited in Bauman, 2000, p. 180) dialectically and inwardly indicates "the 'they' feeling". Therefore, just as common enemies can be an inspirational reason for common friendships, the sense of community or the sense of togetherness may indirectly be nourished by its antithetical parameters: viz., hostility, hate, competition, jealousy, arrogance, discrimination, etc.

In any case, the 'we' feeling functions as a sort of defense mechanism in a world of variety, conflict and chaos. Those who gather around the 'we' feeling do not need to know each other. The working principle of the mechanism is based essentially on the desire and aim to be similar and together. In return, as a prize, it makes a promise to the Umut and Cemile:

The drive towards a 'community of similarity' is a sign of withdrawal not just from the otherness outside, but also from the commitment to the lively yet turbulent, engaged yet cumbersome interaction inside. The attraction of the "community of sameness' is that of an insurance policy against the risks with which the daily life in a poly-vocal world is fraught. (Bauman, 2003b, p. 32)

This enthusing offer encourages them to become members of a respected community. Thus, they find ready-made islands that can be entered without any passport or customs control and which are inhabited by similar people. Nevertheless, this offer - this prize of obtaining the privileged golden membership - is not unconditional. For instance, the first thing that they have to give up in exchange for a secure community image is their freedom.

According to Bauman, community is the antibook of freedom because community entails a sameness which is diametrically opposed to subjectivity (2001, p. 115). In addition, the proximity which communities provide turn into a confinement when appropriate (Bauman, 2001, p. 116). Far from unifying or repairing identities, it divides good from evil and 'us' from 'them' by producing strongly-woven identities and moral values. These standards, which fictionalize the community as being a kind of utopia (Bauman, 2000, p. 92), determine who is inside and who is outside of the circle (Bauman, 1994, pp. 26-27). Hence, each island on which Umut and Cemile attempt to settle becomes, with time, isolated and encircled with indestructible, impassable walls. At this stage, each island, beyond being an innocent division and segregation, becomes the focal 
point of the camp in which the other resides, and all of those living in that camp are perceived as aliens who should be destroyed. For this reason, even if the home in this community narrative is portrayed as the safe antibook of fragile streets, neither the home nor the institution of family, which is the essence of community, adequately produce the serenity or security which were wished for, indeed.

\section{Conclusion}

'Where one is' is largely related to who s/he is and vice versa. The two characters in the film are outsiders who want to change their status by shifting their spatial position from the corners of the city to its center which, itself, is surrounded by both visible and invisible walls. Each of them, but mostly Cemile desires to have more luxurious houses or more vivacious homes in which they could feel free and calm. In this regard, as far as the film itself is concerned, the problem is not only a spatial case but also a matter of social design. Perhaps the best solution for Cemile and Umut is to try to shift their mental as well as spatial positions from being within the society to being outside of it.

There seem two choices at this juncture: to create an environment in which surveillance is minimised and in which they have the free-will to stay or leave at anytime; or to assimilate into the society and environment which already exists there. Consequently, living in the city (Istanbul) is metaphorically like staying in a hotel. Everyone is a traveler in that hotel. Since nobody knows each other exactly, its atmosphere is full of a sense of distrust. On the one hand, it is certain that nobody can stay there forever; but, on the other hand, there is a doubt and uncertainty about who will have to leave first, as well as when they will have to leave. The hotel is costly, and those who cannot pay must find a remedy, like getting into debt; otherwise, they leave.

There is a forced circulation in the hotel. Rooms are being perpetually occupied and vacated. Those who are not accepted into the hotel are able to build rooms on the roof illegally. This may show that the hotel is a flexible and enlargeable construction. However, even though it at first invites, it later rejects; even though it at first welcomes with open arms, it later strangles kindly; even though it at first gives hope, it later disappoints; even though it at first gives unconditionally, it later takes more than it gave. This is the story of the Köprüdekiler. This is the manifestation of the city, home and family.

\section{References}

Akın, F. (2012). “11'e 10 Kala”. Available at: http://www.menonthebridge.com/. [Accessed 20 December 2012].

Alver, K. (2010). Steril Yaşamlar, Ankara: Hece Yayınları.

Bauman, Z. (1994). Alone Again: Ethics after Certainty, London: Demos.

Bauman, Z. (1997). Postmodernity and its Discontents, Oxford and Cambridge: Polity Press.

Bauman, Z. (1999a). In Search of Politics, Stanford: Stanford University Press.

Bauman, Z. (2000). Liquid Modernity, Cambridge and Malden: Polity Press.

Bauman, Z. (2001). Community: Seeking Safety in an Insecure World, Cambridge, Oxford and Malden: Polity Press.

Bauman, Z. (2003a). Liquid Love: On the Frailty of Human Bonds, Cambridge, Polity Press; Oxford: Blackwell Publishers Ltd.

Bauman, Z. (2003b). City of Fears, City of Hopes, London, Goldsmiths College: University of London Press.

Demir, S. T. (2014). “The City on Screen: A Methodological Approach on Cinematic City Studies", CINEJ Journal 4 (1): 21-36.

Diken, B. and Laustsen, C. B. (2007). Sociology through the Projector, London and New York: Routledge.

Dowd, J. (1999). "Waiting for Louis Prima: On the Possibility of a Sociology of Film, Teaching Sociology". Teaching Sociology, 27 (4), 324-342. 
Lapsley, R. (1997). Mainly in Cities and at Night: Some Notes on Cities and Film. In Clarke, David. B. (Ed.) The Cinematic City. New York and London: Routledge.

Lefebvre, H. (1996) Writings on Cities, Malden and Massachusetts: Blackwell.

Ruskin, J. (1891). Sesame and Lilies, New York: Metropolitan Publishing Co.

Sennett, R. (1992). The Conscience of the Eye: The Design and Social Life of Cities, New York and London: W. W. Norton and Company Inc.

Sennett, R. (1996). The Uses of Disorder: Personal Identity and City Life, London: Faber and Faber.

Sennett, R. (1998). The Corrosion of Character: Personal Consequences of Work in the New Capitalism: New York, W. W. Norton and Company, Inc.

Sennett, R. (2003). Respect: The Formation of Character in a World of Inequality, London, New York, Victoria, Toronto, New Delhi, Auckland and Rosebank: Penguin Books.

Simmel, G. (1971). On Individuality and Social Forms, Chicago and London: The University of Chicago Press.

\section{Acknowledgements}

I would like to thank my supervisors Prof. Bülent Diken and Dr. Graeme Gilloch at Lancaster University for their guidance in improving this paper, which is written as a chapter of my $\mathrm{PhD}$ thesis. 